\title{
Concept for a LNG Gas Handling System for a Dual Fuel Engine
}

\author{
Michael Rachow ${ }^{1}$, Steffen Loest ${ }^{2}$, Leonardo Risman Maruli Sitinjak ${ }^{3}$
}

\begin{abstract}
LNG as main engine fuel because based on the facts that LNG has no sulphur content, and its combustion process, LNG produces low NOx content compared to heavy fuel oil and marine diesel oil. LNG is not only produces low gas emission, but may have economic advantages. In the engine laboratory of maritime studies department in Warnemunde, Germany, there is a diesel engine type MAN 6L23/30 A, where the mode operation of these engine would be changed to dual fuel engine mode operation. Therefore, in this research, the use dual fuel engine will be compared where it will utilize natural gas and marine diesel oil and select the required components for fuel gas supply system. By conducting the process calculation, engine MAN 6L23/30 A requires the capacity natural gas of $12.908 \mathrm{~m}^{3}$ for 5 days at full load. A concept for LNG supply system would be arranged from storage tank until engine manifold. Germanischer Lloyd and Project Guide of dual fuel engine will be used as a guidelines to develop an optimal design and arrangement which comply with the regulation.
\end{abstract}

Keywords-liquefied natural gas (LNG), dual fuel engine, fuel gas consumption analysis, concept of LNG supply system.

\section{INTRODUCTION}

$\mathrm{L}$ iquefied natural gas (LNG) has been used as marine fuel for more than 50 years since the world's first commercial seaborne trade of LNG began in 1964, shipping LNG from Algeria to the U.K [1]. The liquefied natural gas as a marine fuel is regarded as a proven solution for marine applications. The number of ships using LNG as fuel is increasing fast and more and more infrastructure projects are planned or proposed along the main shipping lanes. 63 LNG-fuelled ships (excluding LNG carriers) already operate worldwide, while another 76 new buildings are confirmed (as of May 2015) [2].

The main emission product from a diesel engine are $\mathrm{CO}_{2}, \mathrm{NO}_{\mathrm{K}}, \mathrm{SO}_{\mathrm{x}}$ and particulate matter (PM). These emissions can increasing the temperature on earth, affect the air quality, global warming and other health problems that can impact the environmental. The use of LNG as marine fuel is the proven solution and will contribute to a reduction of these emissions. These reductions will have significant environmental benefits such as improved local air quality, reduced acid rain and contribute to limit global warming [3-19].

According to DNV GL, when LNG is used as a ship fuel and in the replacement of conventional oil-based fuels (heavy fuel oil, marine gas oil, or distillate fuels) is the significant reduction in local air pollution - ranging from emissions of $\mathrm{SO}_{\mathrm{x}}$ and $\mathrm{NO}_{\mathrm{x}}$ to carbon dioxide, particulates (PM) and black carbon. The complete removal of $\mathrm{SO}_{\mathrm{x}}$ and particle $\mathrm{PM}$ emissions and a reduction of $\mathrm{NO}_{\mathrm{x}}$ emission of up to $85 \%$ by using $\mathrm{LNG}$ is a strong argument for the use of LNG, especially in

Michael Rachow, Department of Maritime Studies, Hochschule Wismar, Wismar, 23966, Germany. E-mail: michael.rachow@hswismar.de

Steffen Loest, Department of Maritime Studies, Hochschule Wismar, Wismar, 23966, Germany. E-mail: steffen.loest@hs-wismar.de

Leonardo Risman Maruli Sitinjak, Department of Marine Engineering, Institut Teknologi Sepuluh Nopember, Campus ITS Sukolilo-Surabaya, 60111, Indonesia. E-mail: leonardorismansitinjak@gmail.com coastal and sensitive ecosystems. In addition, LNG also reduces $\mathrm{CO}_{2}$ emissions by at least $20 \%$. As a fuelling option, LNG offers multiple advantages to both human health and the environment.

One of the main reason that makes LNG become the preferable fuel is the lower price compared to Heavy Fuel Oil (HFO), Marine Diesel Oil (MDO) and Low Sulphur Heavy Fuel Oil (LSHFO). DNV GL was made fuel price scenario for the basic assumption. Starting year for the fuel price scenario is 2010 and $650 \$ / \mathrm{t}$ $(=15.3 \$ / \mathrm{mmBTU})$ for $\mathrm{HFO}$ and $900 \quad \$ / \mathrm{t} \quad(=21.2$ $\$ / \mathrm{mmBTU})$ for $\mathrm{MGO}$ are set. $\mathrm{LNG}$ is set at 13 $\$ / \mathrm{mmBTU}$ which includes small-scale distribution costs of $4 \$$ mmBTU [3-11].

\section{METHOD}

\section{A. Problem of Statement}

In this research, the main problem is changing the engine operation mode from diesel to dual fuel which installed inside the engine laboratory, at the department of maritime studies in Warnemünde. The diesel engine type is MAN 6L23/30A. According to the problem above, it generated problem formulation, such as gas consumption at variation loads, components of the gas supply system, design P \& I concept including special requirements and safety aspects.

\section{B. Literature Study}

Literature study is the stage to get all the information to solve the problem obtained. Many information should be obtained, such as basic theory of LNG characteristics, how to calculate the fuel oil and fuel gas consumption, what are the supporting components of fuel gas supply system, what is the consideration to design the concept of fuel gas supply system, how to install the required component into the laboratory building and many others. Most of the information regarding concept design of fuel gas supply system can be obtained from Germanischer Lloyd as classification society and dual fuel engine project guide. Some information are also can be obtained from papers, journals, research and researches that able to support this research. 


\section{Collecting Data}

In this stage, data collection is required to develop the concept of fuel gas supply system. The data supported in this research are engine specifications, dual fuel engine project guide, and classification regulation of gas supply systems. Engine project guide is required to find out the engine specifications and engine dimensions. In this research, the calculation of fuel oil consumption and vaporizer is based on data actual of engine operation. Therefore, the engine will be operated to get the actual data of specific fuel oil consumption (SFOC), engine water cooling temperature and exhaust gas temperature.

\section{Fuel Oil Consumption Calculation}

In this stage, fuel oil consumption will be calculated in several variations of load, such as $10 \%, 25 \%, 50 \%, 75 \%$, and $100 \%$. The fuel oil consumption will be calculated based on the data from project guide and data actual of engine operation. Therefore, SFOC from project guide 6L23/30 A MAN is required to calculate the fuel consumption. The data actual of SFOC will be obtained after the engine operated.

\section{E. Fuel Gas Consumption Calculation}

In this stage, fuel gas consumption will be calculated to find out the storage tank capacity to store the fuel for certain time of operation, fuel pump capacity, vaporizing system and gas valve unit specification. The value of specific fuel gas consumption (SFGC) is required to calculate the fuel gas consumption. There is no information about SFGC for engine MAN 6L23/30 A. Therefore, the dual fuel engine project guide is needed as reference to get the value of SFGC, such as MAN 51/60 DF, MAN 35/44 DF and Wartsila 34 DF. These engine was converted from single fuel to dual fuel engine. The value of SFGC from each dual fuel engine project guide will be compared and choose the correct one as reference to calculate the fuel gas consumption of engine MAN $6 \mathrm{~L} 23 / 30 \mathrm{~A}$.

\section{F. Determine the Required Components of Fuel Gas Supply System}

This stage is aims to analyse the components required for gas supply system and the decision of components is based on the classification society and dual fuel engine project guide. Germanischer Lloyd regulation will be used as the classification society. The essential components is required to support the fuel gas supply system, such as LNG tank, water spray pump, LNG pump, vaporizer, and gas valve unit (GVU). All the specification of these components will be obtained based on the fuel gas consumption result. The output of this stage is to determine the required components that meet to the engine requirement, dual fuel engine project guide, and classification societies.
G. Design the Concept of Fuel Gas Supply System

After every consideration is met the requirement, then the next step is design the fuel gas supply system. In this stage, to design a P\&I concept including special requirements for LNG and safety aspects from store tank until engine manifold. Safety aspects will be arranged according to Germanischer Lloyd regulation, component manufacturer requirement, and dual fuel engine project guide.

\section{H. Installation Suggest for the Plant}

After the concept design of fuel gas supply system met to the regulation and project guide of dual fuel engine, then all the components can be installed to the laboratory. In this stage, the placement location of each component will be considered because the laboratory at the department of maritime studies in Warnemünde has limited space. The consideration of installation suggest for the components of fuel gas supply system in the laboratory building should be based on the classification societies.

\section{Conclusion}

The conclusion of this research is to obtain the optimum concept design of gas supply system and safety aspects from storage tank until engine manifold that based on Germanischer Lloyd regulation and dual fuel engine project guide.

\section{RESUlTS AND DISCUSSION}

\section{A. Engine Overview}

This research use engine type MAN 6123/30 A as case study. The engine is installed inside the engine laboratory, at the department of maritime studies in Warnemünde. This engine had a power of $960 \mathrm{~kW}$ and use marine diesel oil (MDO) as the main fuel. This engine is equipped with water brake system. A water brake system is a type of fluid coupling used to absorb mechanical energy and usually consists of a turbine or propeller mounted in an enclosure filled with water. The water brake is utilized to measure the power output of the engine. The basic operation of a water brake uses the principle of viscous coupling. The output shaft of the engine is coupled to a fan that spins inside a concentric housing. While the engine is running, the housing is filled with a controlled amount of water. The more water that is allowed into the housing, the more load the engine will feel. According to the figure 1 below, the water brake in the engine laboratory, at the department of maritime studies in Warnemünde is indicated with a green colour. The manufacturer of the water brake is Zöllner type 9N38/12F. It has maximum power of 1200 $\mathrm{kW}$ and maximum speed of $3500 \mathrm{r} / \mathrm{min}$. The required ofwater capacity of this water brake is $25.2 \mathrm{~m}^{\mathrm{a}} / \mathrm{h}$. The water temperature of water brake system should be maintained around $40^{\circ} \mathrm{C}$. 


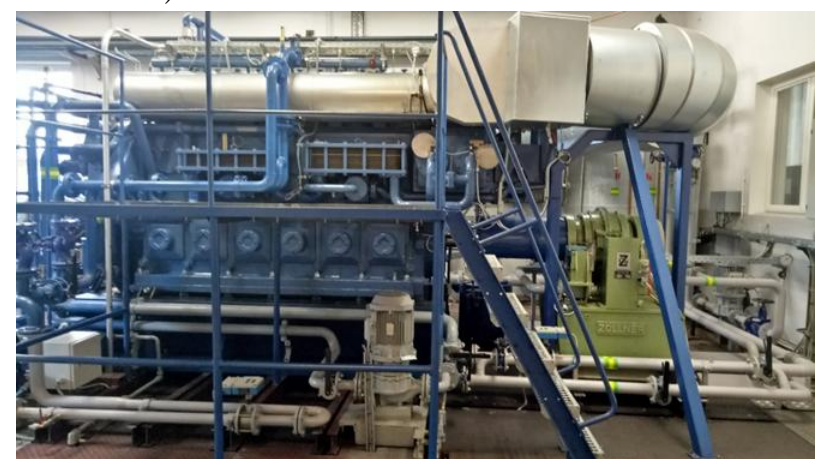

Figure. 1. Engine Type MAN 6L23/30 A and Water Brake Type Zöllner 9N38/12F

\section{B. Fuel Oil Consumption Analysis}

Fuel oil consumption calculation is required to find out the fuel gas tank volume. There are 4 parameters to calculate the fuel oil consumption, as it can be seen in formula 3.1 below. Main engine is not working in 24 hours per day. It is only working in 8 hours per day and the volume of fuel gas tank will be calculated for demand 5 days. Before calculate the fuel gas consumption, it's necessary to calculate the fuel oil consumption. In this study, fuel oil consumption will be calculated at variation loads by using formula 1 below.

$$
\mathrm{FOC}_{\text {load }}=\mathrm{BHP}_{\text {load }} \times \mathrm{SFOC}_{\text {load }} \times \mathbf{t} \times 10^{-6}
$$

In this research, there is a differences between value of Specific Fuel Oil Consumption (SFOC) that attached in project guide MAN 6L23/30A and data actual from engine operation. In data retrieval, engine will be operated in variation loads as table 1 below. By using formula 1 and table 1 above, the result calculation of fuel oil consumption can be seen in table 2 below.

TABLE 1.

SPECIFIC FUEL OIL CONSUMPTION

\begin{tabular}{ccccc}
\hline $\begin{array}{c}\text { Loads } \\
(\boldsymbol{\%})\end{array}$ & $\begin{array}{c}\text { Power } \\
(\mathbf{k W})\end{array}$ & RPM & $\begin{array}{c}\text { SFOC from Project Guide } \\
(\mathbf{g} / \mathbf{k W h})\end{array}$ & $\begin{array}{c}\text { SFOC from Data Actual } \\
(\mathbf{g} / \mathbf{k W h})\end{array}$ \\
\hline 12 & 115 & 490 & 229 & 246.96 \\
\hline 25 & 240 & 570 & 217 & 228.33 \\
\hline 50 & 480 & 714 & 197 & 218.13 \\
\hline 75 & 720 & 820 & 193 & 207.78 \\
\hline 100 & 960 & 903 & 194 & 209.06 \\
\hline
\end{tabular}

TABLE 2.

RESULT OF FUEL OIL CONSUMPTION CALCULATION

\begin{tabular}{ccc}
\hline \multirow{2}{*}{$\begin{array}{c}\text { Loads } \\
(\%)\end{array}$} & \multicolumn{2}{c}{ Fuel Oil Consumption } \\
\cline { 2 - 3 } & Based on Project Guide (ton) & Based on Data Actual (ton) \\
\hline 12 & 0.18 & 0.19 \\
\hline 25 & 0.42 & 0.44 \\
\hline 50 & 0.76 & 0.84 \\
\hline 75 & 1.11 & 1.20 \\
\hline 100 & 1.49 & 1.60 \\
\hline
\end{tabular}

\section{A. LNG Consumption Analysis}

The calculation of LNG consumption is required to determine the capacity of storage tank. This calculation is using formula as shown in formula 1 . When the diesel engine is converted to dual fuel engine, the engine power will decrease due to the differences of lower heating value (LHV) between fuel oil and LNG. LHV is the amount of heat released when a specified amount of fuel (usually a unit of mass) at room temperature is completely burned. The power decreasing and the value of specific fuel gas consumption (SFGC) for engine MAN 6L23/30 A will be obtained and analyzed based on the dual fuel engine project guide, such as MAN 51/60 DF, MAN 35/44 DF, and Wartsila 34 DF.
- Power Reduction of Engine MAN 6L23/30 A

In this research, the amount of power reduction of MAN 23/30 $\mathrm{A}$ is referenced by the engine which has been converted to dual-fuel engines. Engine that will serve as the reference for calculating the power reduction is MAN 48/60 B converted to MAN 51/60 DF, MAN 32/44 CR converted to $35 / 44 \mathrm{DF}$, and Wartsila 32 converted to Wartsila 34 DF (see table 3 below). To find out the amount of power reduction of MAN 6L23/30 A, it should be calculate the power per cylinder volume. Therefore, power per cylinder volume of each engine can be seen in the figure 2 below. Based on the results from figure 2 below, thus the magnitude of power reduction per cylinder/swept volume of each engine can be seen in the table 4 below. 
TABLE 3.

SPECIFICATIONS OF MAN 48/60 B, MAN 51/60 DF, MAN 32/44 CR, MAN 35/44 DF, WARTSILA 32, AND WARTSILA 34 DF

\begin{tabular}{|c|c|c|c|c|c|c|c|}
\hline \multirow[b]{2}{*}{ No } & \multirow[b]{2}{*}{ Parameter } & \multicolumn{6}{|c|}{ Engine Type } \\
\hline & & $\begin{array}{c}\text { MAN } \\
48 / 60 \text { B }\end{array}$ & $\begin{array}{c}\text { MAN } \\
51 / 60 \text { DF }\end{array}$ & $\begin{array}{c}\text { MAN } \\
\text { 32/44 CR }\end{array}$ & $\begin{array}{c}\text { MAN } \\
\text { 35/44 DF }\end{array}$ & $\begin{array}{c}\text { Wartsila } \\
32\end{array}$ & $\begin{array}{c}\text { Wartsila } \\
34 \text { DF }\end{array}$ \\
\hline 1 & Power (kW) & 6900 & 6300 & 3600 & 3060 & 3480 & 3000 \\
\hline 2 & RPM & 500 & 500 & 720 & 720 & 750 & 750 \\
\hline 3 & Cylinder & 6 & 6 & 6 & 6 & 6 & 6 \\
\hline 4 & Bore (mm) & 480 & 510 & 320 & 350 & 320 & 340 \\
\hline 5 & Stroke $(\mathrm{mm})$ & 600 & 600 & 440 & 440 & 400 & 400 \\
\hline 6 & Cylinder Volume (1) & 108.6 & 122.5 & 35.4 & 42.3 & 32.2 & 36.3 \\
\hline
\end{tabular}

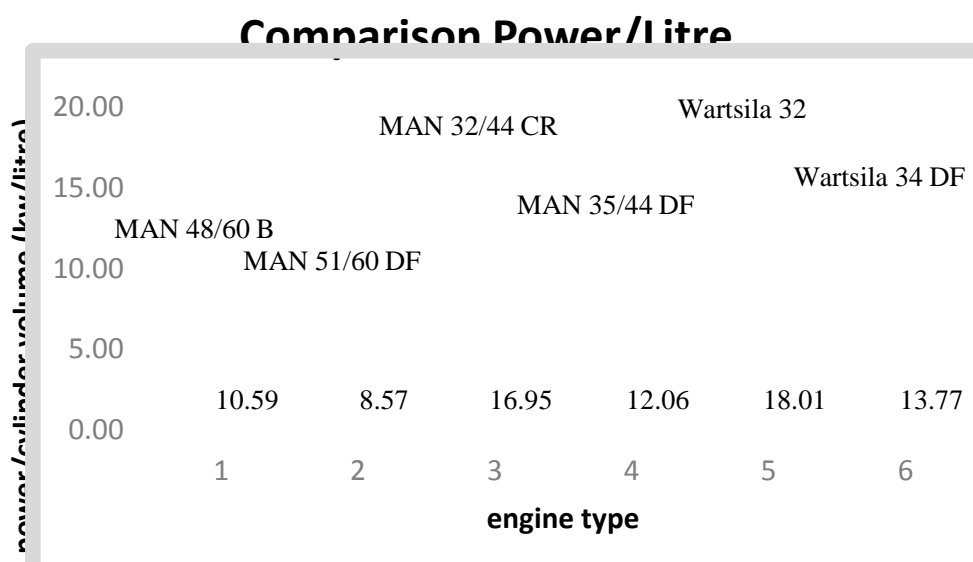

Figure. 2. Result of Power per Cylinder Volume Calculation

TABLE 4.

POWER REDUCTION OF ENGINE CONVERTED TO DUAL FUEL ENGINE

\begin{tabular}{ccc}
\hline No & Engine Converted & Power Reduction \\
\hline 1 & MAN 48/60 B to MAN 51/60 DF & $19.056 \%$ \\
\hline 2 & MAN 32/44 CR to MAN 35/44 DF & $28.87 \%$ \\
\hline 3 & Wartsila 32 to Wartsila 34 DF & $23.53 \%$ \\
\hline
\end{tabular}

To determine the value of power per cylinder volume of engine MAN 6L23/30 A, it should be consider the result of power per cylinder analysis of engine MAN 51/60 DF, MAN 35/44 DF and Wartsila $34 \mathrm{DF}$. According to figure 2 above, the power per cylinder reduction between MAN 35/44 DF and Wartsila 34 DF doesn't have differences significantly. Comparison power per cylinder of MAN 35/44 DF and MAN 51/60 DF have differences significantly. MAN 35/44 DF have less power, less swept volume, and have a higher RPM compared to MAN 51/60 DF. According to the table 4 above, the power per cylinder reduction of MAN 35/44 DF is higher compared to MAN 51/60 DF, it's means when the power is decrease, the cylinder volume is decrease but the RPM is increase, then the reduction of power per cylinder will increase. Therefore, the power per cylinder reduction of MAN 35/44 DF will be used to calculate the power reduction of engine MAN 51/60 DF. Before calculate the power reduction, it require to calculate the power per cylinder volume of engine MAN 6L23/30 A. The data required to calculate the power per cylinder volume are

$\begin{array}{ll}\text { Power } & : 960 \mathrm{~kW} \\ \text { Cylinder } & : 6 \\ \text { Bore } & : 225 \mathrm{~mm}\end{array}$

Stroke : $300 \mathrm{~mm}$

Based on the data above, the power per cylinder volume can be obtained as calculation below

$$
\begin{array}{ll}
\text { Swept Volume } & =\text { Bore }^{2} \times 0.7854 \times \text { Stroke } \\
& =0.225^{2} \times 0.7854 \times 0.3 \\
& =0.01193 \mathrm{~m}^{a} \\
& =11.93 \text { litre } \\
& = \\
\text { Power per Cylinder } \quad & \\
\text { Power/number of cylinders } & =960 \mathrm{~kW} / 6 \\
& =160 \mathrm{~kW}
\end{array}
$$

Power per Cylinder Volume $\quad=$ Power per Cylinder/Cylinder Volume

\section{$160 \mathrm{~kW} / 11.93$ litre}

$$
=13.41^{\mathrm{kW}} / \text { litre }
$$

Thus, the power per swept volume in the engine modified to dual fuel engine be

Power per Cylinder Volume(dual fuel engine)

$=$ Power per Cylinder Volume (diesel engine) $\times(100-28.87) \%$ 
International Journal of Marine Engineering Innovation and Research, Vol. 1(4), Sept. 2017. 272-283 (pISSN: 2541-5972, eISSN: 2548-1479)

$$
\begin{aligned}
& =13.41 \mathrm{~kW} / \text { litre } \times 71.13 \% \\
& =9.54 \mathrm{~kW} / \text { litre }
\end{aligned}
$$

According to the project guide of dual fuel engines that already serve as the reference for calculating the power per cylinder, bore dimension is having changes of 30 $\mathrm{mm}$. Therefore, in this research, the bore dimensions of the engine being $255 \mathrm{~mm}$. Based on these value, swept volume after engine modified to dual fuel engine will be Swept Volume

$$
\begin{aligned}
& =\text { Bore }^{2} \times 0.7854 \times \text { Stroke } \\
& =0.255^{2} \times 0.7854 \times 0.3 \\
& =0.01532 \mathrm{~m}^{\mathrm{a}}
\end{aligned}
$$

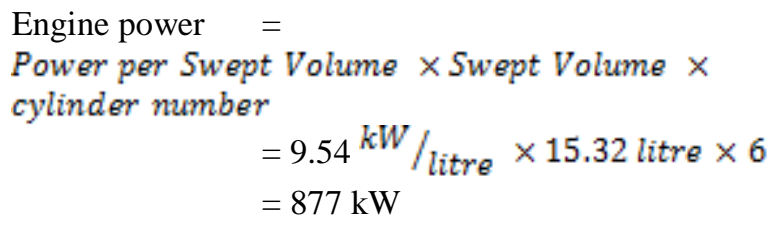

Table 5 below shows the engine power in variation loads after the engine modified to dual fuel engine

TABLE 5.

RESULT OF POWER REDUCTION OF ENGINE MAN 6L23/30 A AT VARIATION LOAD

\begin{tabular}{cccc}
\hline Load (\%) & Power $(\mathbf{k W})$ & SFOC $(\mathbf{g} / \mathbf{k W h})$ & SFOC $(\mathbf{k J} / \mathbf{k W h})$ \\
\hline 100 & 877 & 208.62 & 8908.074 \\
\hline 75 & 657.75 & 210.47 & 8987.069 \\
\hline 50 & 438.50 & 219.90 & 9389.73 \\
\hline 25 & 219.25 & 231.48 & 9884.196 \\
\hline 12 & 105.24 & 250.11 & 10679.697 \\
\hline
\end{tabular}

- Specific Fuel Gas Consumption Analysis

The value of SFOC above is based on the data actual of the engine operation. To determine the LNG consumption, it's requires the specific fuel gas consumption data for natural gas. In this research, the specific fuel gas consumption data of natural gas for
6L23 MAN/30 is obtained from comparative analysis of specific fuel gas consumption of engines that already converted to dual fuel engines such as MAN 51/60 DF, MAN 35/44 DF, and Wartsila 34 DF. Table 6 below shows the results of a comparative analysis of the specific fuel consumption of those engines

TABLE 6.

COMPERATIVE ANALYSIS OF SPECIFIC FUEL GAS CONSUMPTION

\begin{tabular}{ccccccc}
\hline \multirow{2}{*}{ Load (\%) } & \multicolumn{2}{c}{ MAN 51/60 DF } & \multicolumn{2}{c}{ MAN 35/44 DF } & \multicolumn{2}{c}{ Wartsila 34 DF } \\
\cline { 2 - 7 } & $\begin{array}{c}\text { Fuel Oil } \\
(\mathbf{k J} / \mathbf{k W h})\end{array}$ & $\begin{array}{c}\text { Fuel Gas } \\
(\mathbf{k J} / \mathbf{k W h})\end{array}$ & $\begin{array}{c}\text { Fuel Oil } \\
(\mathbf{k J} / \mathbf{k W h})\end{array}$ & $\begin{array}{c}\text { Fuel Gas } \\
(\mathbf{k J} / \mathbf{k W h})\end{array}$ & $\begin{array}{c}\text { Fuel Oil } \\
(\mathbf{k J} / \mathbf{k W h})\end{array}$ & $\begin{array}{c}\text { Fuel Gas } \\
(\mathbf{k J} / \mathbf{k W h})\end{array}$ \\
\hline 100 & 7643 & 7470 & 7665 & 7190 & 8113 & 7470 \\
\hline 85 & - & - & 7558 & 7200 & 7984.9 & 7620 \\
\hline 75 & 8113 & 7810 & 7814 & 7330 & 7984.9 & 7850 \\
\hline 50 & 8412 & 8390 & 7900 & 7820 & 8326.5 & 8600 \\
\hline 25 & 9309 & 11230 & 8540 & 9000 & - & - \\
\hline 10 & 13237 & 18420 & - & - & - & - \\
\hline
\end{tabular}

From the table 6 above, it can be known, at load 50\% $100 \%$ specific fuel gas consumption is smaller compared to the specific fuel oil consumption. While at load $10 \%$ and $25 \%$, specific fuel gas consumption is greater than specific fuel oil consumption. Percentage change of specific fuel consumption of this engines can be seen in the table 7 below.

TABLE 7.

PERCENTAGE CHANGE OF SPECIFIC FUEL GAS CONSUMPTION

\begin{tabular}{cccc}
\hline \multirow{2}{*}{$\begin{array}{c}\text { Load } \\
(\%)\end{array}$} & \multicolumn{3}{c}{ Percentage } \\
\cline { 2 - 4 } & MAN 51/60 DF & MAN 35/44 DF & Wartsila 34 DF \\
\hline 100 & -2.26 & -6.20 & -7.93 \\
\hline 85 & - & -4.74 & -4.57 \\
\hline 75 & -3.73 & -6.15 & -1.69 \\
\hline 50 & -0.26 & -1.01 & 3.28 \\
\hline 25 & 20.64 & 5.39 & - \\
\hline 10 & 39.16 & - & - \\
\hline
\end{tabular}

Data in table 7 above is used as reference to determine the value of specific fuel gas consumption of engine MAN 6L23/30 A. With some of considerations, the average of specific fuel gas consumption (SFGC) of engine MAN 35/44 DF and Wartsila 34 DF will be used to determine the specific fuel gas consumption of engine MAN 6L23/30 A. This engine having speed of 720 RPM and $750 \mathrm{RPM}$, where this speed is approaching to the speed of engine MAN 6L23/30 A, while the engine speed of MAN 51/60 DF is 500 RPM. Therefore, the result of SFGC of engine MAN 6L23/30 A can be seen in table 8 below 
TABLE 8.

RESULT OF TOTAL FUEL GAS CONSUMPTION ANALYSIS OF ENGINE MAN 6L23/30 A

\begin{tabular}{cccc}
\hline \multirow{2}{*}{ Load (\%) } & $\begin{array}{c}\text { Average } \\
\text { Value (\%) }\end{array}$ & \multicolumn{2}{c}{ MAN 6L23/30 A } \\
\cline { 3 - 4 } & -7.065 & 8908.074 & 8279 \\
\hline 100 & -3.92 & 8987.069 & 8635 \\
\hline 75 & 2.145 & 9389.73 & 9591 \\
\hline 50 & & & Fuel Gas \\
\hline
\end{tabular}

The result of specific fuel gas consumption in the table 8 above is the total of specific fuel gas consumption (Natural gas consumption + Pilot fuel consumption). Based on MAN B\&W project guide, Wartsila project guide and DNV GL, the amount of pilot fuel oil is below $1 \%$ of the energy used by the engine. Therefore, the amount of specific fuel consumption of pilot injector and natural gas consumption can be seen in table 9 below

TABLE 9.

SPECIFIC FUEL CONSUMPTION OF PILOT INJECTOR

\begin{tabular}{cccc}
\hline \multirow{2}{*}{ Load (\%) } & \multicolumn{3}{c}{ MAN 6L23/30 A } \\
\cline { 2 - 4 } & $\begin{array}{c}\text { Total Fuel Gas } \\
(\mathbf{k J} / \mathbf{k W h})\end{array}$ & $\begin{array}{c}\text { Pilot Fuel } \\
(\mathbf{k J} / \mathbf{k W h})\end{array}$ & $\begin{array}{c}\text { Natural Gas } \\
(\mathbf{k J} / \mathbf{k W h})\end{array}$ \\
\hline 100 & 8279 & 82.79 & 8196.21 \\
\hline 75 & 8635 & 86.35 & 8548.65 \\
\hline 50 & 9591 & 95.91 & 9495.09 \\
\hline
\end{tabular}

After the specific fuel gas consumption is obtained, the fuel gas consumption at variation loads can be calculated by using formula 1 above. Therefore, the result of fuel gas consumption can be seen in table 10 below.

TABLE 10

RESULT OF FUEL GAS CONSUMPTION ANALYSIS OF ENGINE MAN 6L23/30 A

\begin{tabular}{|c|c|c|c|c|}
\hline \multirow[b]{2}{*}{ Load (\%) } & \multirow[b]{2}{*}{ Power $(\mathbf{k W})$} & \multirow{2}{*}{ Natural Gas (kJ/kWh) } & \multicolumn{2}{|c|}{ LNG Consumption } \\
\hline & & & $\mathrm{Kg} / \mathrm{day}$ & Ton/day \\
\hline 100 & 877 & 8196.21 & 1161.71 & 1.16171 \\
\hline 75 & 657.75 & 8548.65 & 908.75 & 0.90875 \\
\hline 50 & 438.50 & 9495.09 & 672.90 & 0.6729 \\
\hline
\end{tabular}

\section{B. Component Selection of Fuel Gas Supply System}

To supply gas from storage tank to the engine, it required some components below.

\section{LNG Storage Tank}

Tank selection is based on the calculation of fuel consumption per day. In this research, the capacity of LNG tank that will be designed is for endurance of one week (5 days), which means LNG tank should be able to serve the demands of fuel engine for one week (40 hours of engine operation). The type of the tank that will be selected is container tank because it has advantages as described above and also has a tank capacity of smallsized, therefore in this study allows to choose a type of tank container. The selected tank is horizontal cryogenic tank type LC16H22-P with capacity $15.7 \mathrm{~m}^{3}$. It mean this type of tank is able to serve the demand of engine operation for a week. According to the calculation result, the demand of LNG for a week is $12.908 \mathrm{~m}^{3}$. The LNG fuel tank container is fitted with process equipment, namely the valves and instruments required for operational and safety purposes. The LNG fuel tank container is also fitted with a pressure build-up evaporator (PBE) for building up and maintaining an operational pressure of approximately 5 bar in the tank.

\section{Water Spray Pump}

Water spray pump should be installed for supplying water to water spray system. This system is for cooling and fire prevention of storage tank. According to GL VI3-1, Section 3, 3.3.2.2, the system should be designed to cover all areas with an application rate of $101 / \mathrm{min} / \mathrm{m}^{2}$ for horizontal projected surfaces and $41 / \mathrm{min} / \mathrm{m}^{2}$ for vertical surfaces. In this research, the application rate that will be used is $10 \mathrm{l} / \mathrm{min} / \mathrm{m}^{2}$ because the type of the tank is horizontal tank. Therefore, the water spray pump capacity and the diameter pipe of water spray system can be seen in the following calculation.

Where

$$
\mathrm{C}=10 \mathrm{l} / \mathrm{min} / \mathrm{m}^{2} \times \mathrm{A}_{\mathrm{Tank}}
$$

$\mathrm{A}_{\text {Tank }}=$ Surface Area of LNG tank $\left(\mathrm{m}^{2}\right)$

$$
\begin{aligned}
& =63.31 \mathrm{~m}^{2} \\
& =101 / \mathrm{min} / \mathrm{m}^{2} \times 63.31 \mathrm{~m}^{2} \\
& =633.1 \mathrm{litre} / \mathrm{min} \\
& =37.986 \mathrm{~m}^{\mathrm{a}} / \mathrm{h} \\
& =0.01056 \mathrm{~m}^{\mathrm{a}} / \mathrm{s}
\end{aligned}
$$

The selected water spray pump is evergush with having capacity of $38 \mathrm{~m}^{\mathrm{a}} / \mathrm{h}$.

The following formula can be used for determining the diameter of the pipe.

$$
\mathbf{C}=\mathbf{A} \times \mathbf{v}
$$

Where

$\mathrm{C}=$ Capacity $\mathrm{m}^{\mathrm{a}} / \mathrm{h}$

A $\quad=$ The area of the pipe $\left(\mathrm{m}^{2}\right)$

$\mathrm{v} \quad=$ Velocity, $1 \mathrm{~m} / \mathrm{s}$ (Assumed)

So,

$\mathrm{A} \quad=\mathrm{C} / \mathrm{v}$ 


$$
\begin{aligned}
& =0.01056 \mathrm{~m}^{\mathrm{a}} / \mathrm{s} / 1 \mathrm{~m} / \mathrm{s} \\
& =0.01056 \mathrm{~m}^{2} \\
\mathrm{~A} & =\pi \times d^{2} / 4 \\
\mathrm{~d} \quad & =\sqrt{4 A / \pi} \\
& =\sqrt{4 \times 0.01056 / 3.14} \\
& =0.116 \mathrm{~m} \\
& =116 \mathrm{~mm}
\end{aligned}
$$

After the calculation of pipe diameter is done, it's used to find the specification on DIN catalogue. Therefore, the selected types of galvanised carbon steel pipe based on DIN standard is

Inside diameter $: 133.1 \mathrm{~mm}$

Wall thickness $: 5.4 \mathrm{~mm}$

Outside diameter : $138.5 \mathrm{~mm}$

Nominal diameter: DN 125

\section{Vaporizer}

In changing the LNG phase from liquid to gas, vaporizer equipment is required. Vaporizer is a heat exchange medium from liquid to gas where the heat source can be produced from the engine fresh water cooling, exhaust gas, and electric systems. Circulating water vaporizer will be applied to the fuel gas system because it's more profitable compared to steam vaporizer and electric vaporizer. Circulating water vaporizer has a lower cost operation and only need hot water as a source to vaporize LNG. Based on calculation results, the required gas flow rate in $100 \%$ load is $145.214 \mathrm{~kg} / \mathrm{h}$. The selected vaporizer having gas flow rate of $400 \mathrm{~kg} / \mathrm{h}$.

\section{LNG Pump}

LNG pump is required to transfer LNG from storage tank to vaporizer. The LNG pump should be able operate in maximum pressure of $\mathrm{LNG}$ and can operate in low temperature, where the temperature of LNG is $-182{ }^{\circ} \mathrm{C}$. The capacity of LNG pump is determined by engine fuel gas requirement. Based on the calculation of $\mathrm{LNG}$ consumption, the LNG flow rate at maximum load is $0.323 \mathrm{~m}^{\mathrm{a}} / \mathrm{h}$ or $5.383 \mathrm{l} / \mathrm{min}$. Therefore, the selected LNG pump having range capacity from $1.4-8.1 \mathrm{l} / \mathrm{min}$.

\section{Gas Valve Unit}

Before the gas is supplied to the engine, it passes through a Gas Valve Unit (GVU). The main functions of the Gas Valve Unit are to regulate the gas feeding pressure to the engine, and to ensure a fast and reliable shut down of the gas supply. Wartsila provides two different types of gas valve unit. One is the gas valve unit open design (GVU-OD, see figure 4) which requires installation in an explosion-proof gas valve unit room and airlock is required between GVU room and surrounding space. The other is gas valve unit enclosed design (GVU-ED, see figure 3). The gas valve unit enclosed design is a solution where all the equipment is mounted inside a gas tight casing. The GVU with gas tight casing enables the installation of the gas control system directly next to the engine in the engine room (safe area). In this case, the cover acts as the double wall and thus provides for a secure enclosure of the gas control system. This will safely prevent the gas from getting into the safe area in the event of a gas leak in the gas control system. This arrangement allows the GVUED to be placed inside the engine room to minimize installation costs. [4].

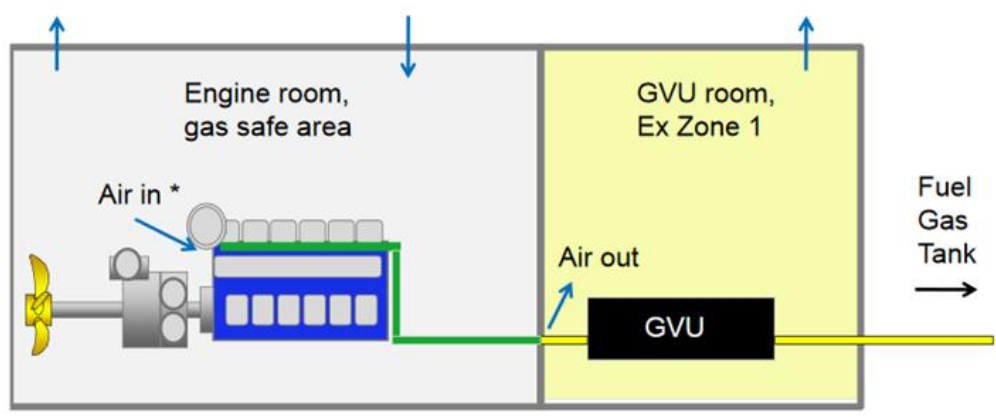

Figure. 3. Gas Valve Unit Enclosed Design

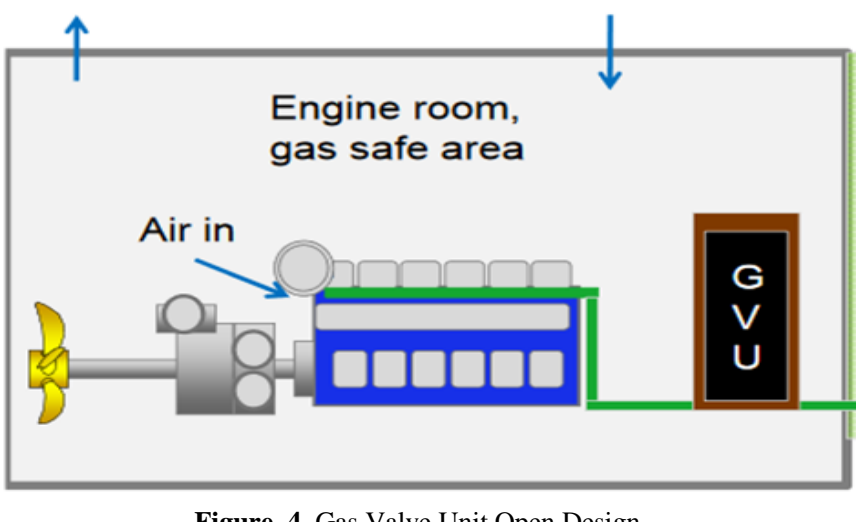

Figure. 4. Gas Valve Unit Open Design

Because of some considerations, in this research, GVU open design will be installed because the engine room in the laboratory doesn't has enough space to install GVU enclosed design. The selected GVU is referenced from 
Wartsila $50 \mathrm{DF}$ product guide, where it's provides two kinds of gas valve unit enclosed design, as shown in table 11 below.

TABLE 11.

TYPES OF GAS VALVE UNIT OPEN DESIGN

\begin{tabular}{ccc}
\hline Pipe Connection & GVU DN80 & GVU DN100 \\
\hline Gas Inlet & DN80 / DN125 & DN100 / DN150 \\
\hline Gas Outlet & DN80 / DN125 & DN100 / DN150
\end{tabular}

In this research, the selected GVU is GVU DN 100 because the result of pipe diameter calculation of fuel gas system is $151.4 \mathrm{~mm}$ or DN150.

\section{E. Design Arrangement}

1. Gas Supply System

Gas fuel supply system is a system which designed to fulfil engine required when engine operated in variation load. In this research, the demand of fuel gas in variation load has been calculated.

Process of gas supply system is started from LNG storage tank where natural gas is in liquid phase. LNG will be transported to vaporizer by using low pressure pump. The capacity of LNG pump is based on gas engine required per hour. Vaporizer type that will installed in this research is the result of comparison between circulating water vaporizer, steam vaporizer and electric vaporizer. In the outlet of vaporizer, natural gas have phase changed from liquid into gas phase.

Before gas flowing to engine, previously gas will through gas valve unit (GVU) where GVU will regulate the pressure and temperature of gas. In every connection in the open spaces will use a double pipe flowline.

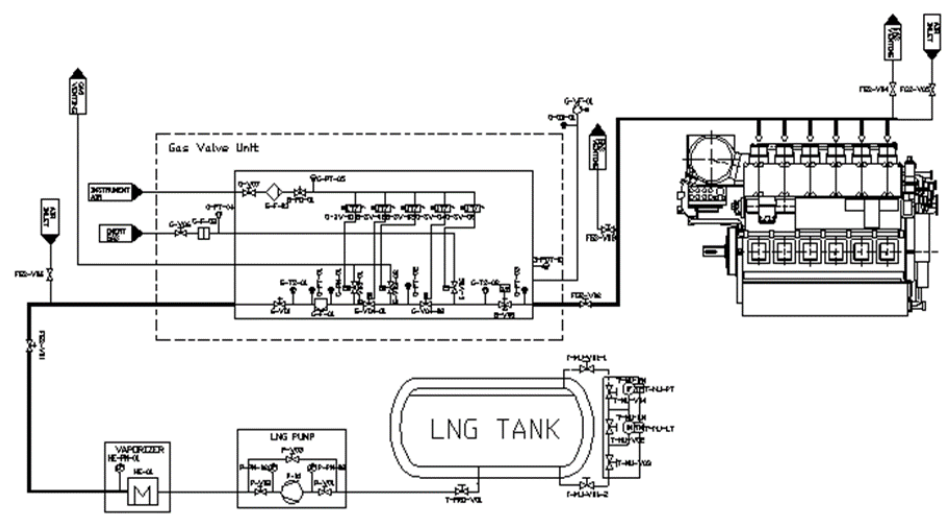

Figure. 5. Design Arrangement of Fuel Gas Supply System

\section{LNG Tank}

In this research, the LNG tank that will be installed is independent tank type $\mathrm{C}$ that having maximum working pressure of 5 bar. Based on GL rules, LNG tank can be located in enclosed deck and open deck. It's not possible to install the LNG tank inside the laboratory or engine room because the laboratory or engine room, at the department of maritime studies in Warnemünde, doesn't have enough space. Therefore, the LNG tank will be installed in the open deck or outside the laboratory. Figure 6 below shows the design arrangement and safety aspects for LNG tank that based on Germanischer Lloyd regulation and LNG tank manufacturer.

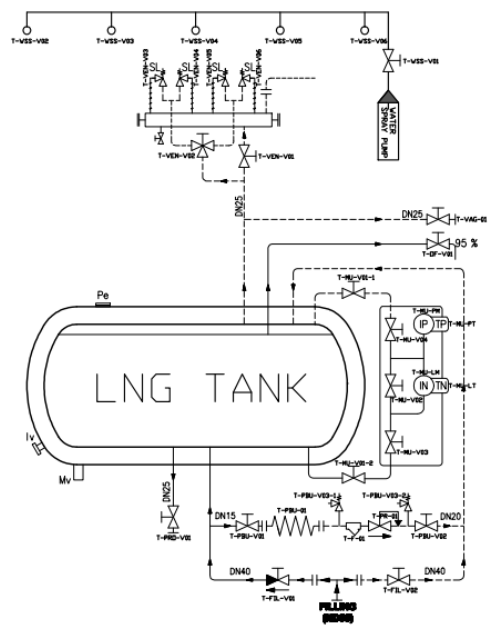

Figure. 6. Design Arrangement of LNG Tank 
a connecting point to the re-fuelling station of LNG tank. Filling connection system also should be fitted with liquid phase non return valve. Its function is to prevent backflow through the fill line.

\section{Venting System}

According to GL VI-3-1, Section 2, 2.8.1.3, pressure relief valve should be fitted to the LNG tank. Single pressure relief valve will be installed because the tank volume not exceeding $20 \mathrm{~m}^{\mathrm{a}}$. According to GL I-1-6, Section 8, 8.2.1, when the volume cargo tank exceeding $20 \mathrm{~m}^{\mathrm{a}}$ is to be fitted at least two pressure relief valve.The pressure relief valve is set at the maximum allowable working pressure (MAWP) of the tank. Based on GL VI3-1, Section 2, 2.8.4.1, gas in liquid state may be stored with a maximum allowable working pressure of 10 bar. Therefore, its function is to vent product to atmosphere if the tank pressure exceeding of $10 \mathrm{bar}$. In the venting system also equipped with line safety valve. Its function is to vent produce to atmosphere in the event of a malfunction of the pressure relief valve.

\section{Pressure and Level Indicator for LNG Tank}

According to GL VI-3-1, Section 5, 5.2.1 and 5.2.2, storage tank should be monitored with overfilling and pressure indicator. Where, storage tanks for liquid gas should not be filled to more than $95 \%$ of tank capacity and the maximum working pressure of 10 bar inside the storage tank. This number is based to the GL rules and LNG tank manufacturer. Therefore, a liquid level and pressure indicator should be fitted to prevent the LNG tank from becoming liquid full and over pressure.

\section{Pressure Build-up Unit}

In the pressure build-up process, cold LNG is drained from the tank bottom to the PBU. The flow is controlled by valve which located before the PBU on figure 5.2 above. According to the LNG tank manufacturer, the operation pressure is set 5 bar. When the pressure drops below 4.5 bar, the PBU is activated and it is de-activated when the tank pressure increases above 5 bar. PBU cycle is driven by the thermosyphon effect: the flow through the PBU is not driven mechanically by a pump or similar, but by the heat transferred into the circuit in the PBU. The difference in density between LNG and NG gives a difference in the static pressure between the section from the liquid surface in the tank to the bottom of the PBU and the section from the bottom of the PBU through the PBU and back to the liquid surface. This enables the fluid to flow around in the circuit [5]. PBU converts liquid from the tank into gas and returns it to the tank, as a result of which the pressure in the tank can be increased.

\section{Water Spray System}

According to GL VI-3-1, Section 3, 3.3.2.1 and 3.3.2.2, when the storage tank located on open deck, a water spray system should be fitted for cooling and fire prevention. The system should arranged to cover all areas with an application rate of $101 / \mathrm{min} / \mathrm{m}^{2}$ for horizontal projected surfaces and $4 \mathrm{1} / \mathrm{min} / \mathrm{m}^{2}$ for vertical surfaces.

The capacity of the water spray pump should be sufficient to deliver the required amount of water as specified in GL VI-3-1, Section 3, 3.3.2.2. The capacity of water spray pump can be seen in chapter 4.2. The system shall be initiated automatically by the fire detection system. On detection of fire on any one storage tank, the water spray system on an adjacent storage tank shall operate by opening the control valve (spray valve). Construction materials can be chosen by the client, based on the possible corrosive properties of the environment or of the used water. Control valves can be made of cast steel as well as from bronze, alubronze, stainless steel or duplex steel. Spray nozzles can be made of bronze or stainless steel. Piping shall be made of galvanized carbon steel [6].

\section{Ventilation in double piping system}

According to GL VI-3-1, Section 2, 2.7.1.1, gas piping system should be arranged with double wall piping. The space between the gas fuel piping and the wall of the outer pipe or duct should be equipped with mechanical under pressure ventilation. Ventilation air inlet is located at the engine and the outside of the tank connection space at the end of the double wall piping. Ventilation air is recommended to be taken from the outside of the engine room and safe area and equipped with a valve to regulate the air flow. The requirement of air exchange in double piping system is minimum 30 air changes per hour, these number is based of classification societies of Germanischer Lloyd. Air flowing will be supplied to Gas Valve Unit room or to the enclosure of the gas valve unit. From the enclosure of the gas valve unit, the air will be ventilated by using ventilation fans and the air will be supplied to the safe area. According to GL rules, the ventilated air outlet should be placed in a position where no flammable gas and air mixture may be ignited and should be installed the gas detector to control any losses of the required ventilating capacity.

\section{Gas Valve Unit}

In gas valve unit (GVU) system, there are 6 pipes connections, such as: gas inlet connection, gas to engine connection, inert gas connection, gas venting connection, air venting connection, and instrument air connection. Gas is flowing to GVU system through gas inlet connection where the gas pressure is $5-10 \operatorname{bar}(\mathrm{g})$. Gas will be filtered by a filter with maximum mesh width must be $0.005 \mathrm{~mm}$ [7]. The pressure loss at the filter is monitored by a differential pressure gauge. Before entering the engine, the gas pressure will be measured by pressure gauge, and gas also through double block and bleed valves. 


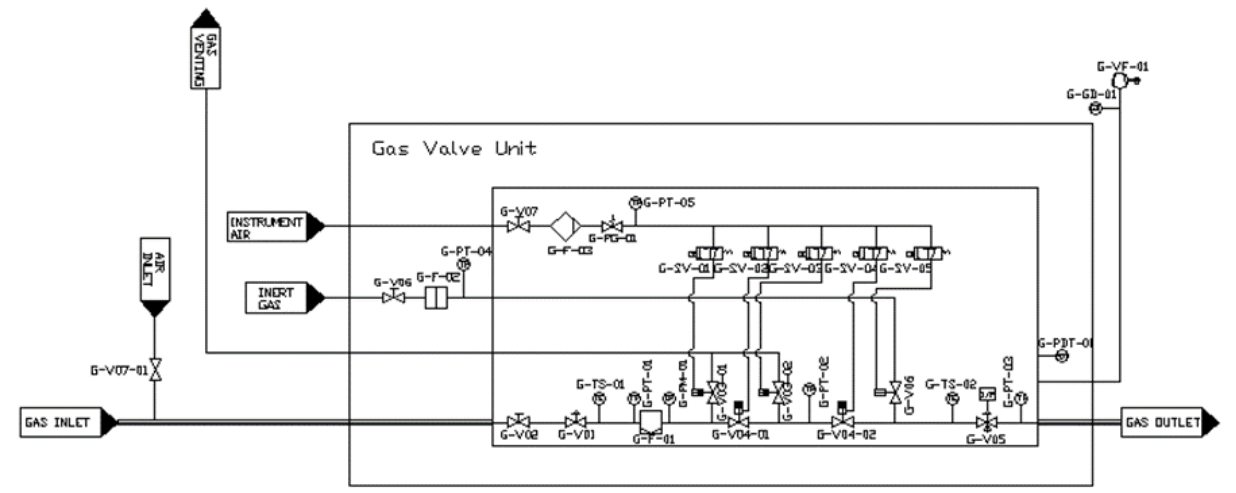

Figure. 7. Design Arrangement of Gas Valve Unit

According to GL GL VI-3-1, Section 5, 5.6.3, fuel gas supply system should be provided with double block and bleed valves. Block valve will open when there is no failure occurred in the system. In the event of a failure in the gas supply system then the block valve will be closed and venting valve or bleed valve will automatically open. The function of the vent valve is to reduce the pressure of the gas in the pipeline and the gas can be ventilated outside the atmosphere. Connecting the engine or venting lines to the GVU LNGPac venting mast is not allowed, due to risk for backflow of gas into the engine room when LNGPac gas is vented. In gas valve unit system, there is a gas double wall system ventilation fan connection for supplying the air inside the GVU room to the safe area. According to GL rules, the maximum of ventilation fan capacity is 30 times per hour and the maximum length of the fuel gas pipe between GVU and gas inlet at engine should be kept as short as possible and not exceed $30 \mathrm{~m}$.

\section{Inert gas system}

In gas valve unit system, there is a gas inert connection where before maintenance work is commenced on the engine and/or the GVU, it is required that any remaining natural gas is removed by substituting the natural gas with an inert gas, for example nitrogen. The GVU inerting process ensures that natural gas cannot leak to the surrounding areas, thus eliminating potential risks. If there is a failure of fuel gas supply system, block valve will be automatically closed and vent valve will be automatically opened. During this situation, the piping will be automatically purged with inert gas system, therefore on the dual fuel engine, an inert gas valve should be installed. In case the nitrogen purging system fails, the gas pipe is once purged with charge air and a gas blocking is set. Thus an explosive atmosphere can only occur seldom and for short periods. Operation in gas mode is only possible if Nitrogen pressure is available and gas blocking alarm has been reset by operator.

\section{CONCLUSIONS}

Based on the calculation result and design process of concept fuel gas supply system for laboratory, at the department of maritime studies in Warnemünde, there are some conclusions can be obtained as below:

1. The LNG and fuel gas consumption calculation of engine MAN 6L23/30 $\mathrm{A}$ is as table 12 below

TABLE 12

LNG AND FUEL GAS CONSUMPTION PER DAY

\begin{tabular}{ccc}
\hline \multicolumn{3}{c}{ MAN 6L23/30 A } \\
\hline Loads & $\begin{array}{c}\text { LNG Consumption } \\
\left(\mathbf{m}^{\mathbf{3}} / \mathbf{d a y}\right)\end{array}$ & $\begin{array}{c}\text { Natural Gas Consumption } \\
\left(\mathbf{m}^{\mathbf{3}} / \mathbf{d a y}\right)\end{array}$ \\
\hline $100 \%$ & 2.58 & 1548 \\
\hline $75 \%$ & 2.02 & 1212 \\
\hline $50 \%$ & 1.50 & 900 \\
\hline
\end{tabular}

Natural gas consumption is required to determine the specification of vaporizer, pipe diameter, and gas valve unit specification. According to natural gas facts (2004), the original volume of the LNG being converted into natural gas by a factor 600. LNG consumption calculation result is required to determine the capacity of LNG tank. In this LNG tank arrangement, the LNG tank should be able to serve the engine operation during one week (5 days). Based on the calculation result, the total LNG consumption per week is $12.908 \mathrm{~m}^{\mathrm{a}}$.

2. The selected components of fuel gas supply system can be seen in table 13 below 
TABLE 13

\begin{tabular}{|c|c|c|}
\hline Object & $\begin{array}{c}\text { Value } \\
\text { LNG Tank }\end{array}$ & Measurement Unit \\
\hline Series & $2200 \mathrm{H}$ & \\
\hline Model & LC16H22-P & \\
\hline Volume & 15.7 & $\mathrm{~m}^{\mathrm{a}}$ \\
\hline $\begin{array}{l}\text { Stored Liquid } \\
\text { Weight at } 95 \%\end{array}$ & 6.9 & Ton \\
\hline \multicolumn{3}{|c|}{ Water Spray Pump } \\
\hline Manufacturer & Evergush & \\
\hline Type & XА50/26 & \\
\hline $\mathrm{Q}$ & 38 & $\mathrm{~m}^{\mathrm{a}} / \mathrm{h}$ \\
\hline Head & 19.8 & $\mathrm{~m}$ \\
\hline Speed & 1450 & RPM \\
\hline Required Motor & 4 & $\mathrm{~kW}$ \\
\hline \multicolumn{3}{|c|}{ Vaporizer } \\
\hline Vaporizer Type & Circulating Water & \\
\hline Model & VWB-400 & \\
\hline LNG Flow Rate & 400 & $\mathrm{~kg} / \mathrm{h}$ \\
\hline Water Flow Rate & 5.1 & $\mathrm{~m}^{\mathrm{a}} / \mathrm{h}$ \\
\hline \multicolumn{3}{|c|}{ LNG Pump } \\
\hline Manufacturer & Vanzetti & \\
\hline Type & VT-1 3225 & \\
\hline $\mathrm{Q}$ & $1.4-8.1$ & lpm \\
\hline Power Installed & $3-15$ & $\mathrm{~kW}$ \\
\hline \multicolumn{3}{|c|}{ Gas Valve Unit } \\
\hline Manufacturer & Wartsila & \\
\hline Type & GVU DN 100 & \\
\hline
\end{tabular}

3. In this concept design of fuel gas supply system, there are three types of piping system that should be installed, such as pipe for liquid phase from LNG tank until the input of vaporizer, pipe for gas phase from output of vaporizer until engine manifold and pipe for water spray system. All the dimensions are accordance to DIN standard. The dimension of this pipe can be seen in table 14 below

TABLE 14. PIPE DIAMETER DIMENSION

\begin{tabular}{|c|c|c|}
\hline Object & Value & Measurement Unit \\
\hline \multicolumn{3}{|c|}{ Pipe Dimension of Gas Phase } \\
\hline Inside Diameter & 152.4 & $\mathrm{~mm}$ \\
\hline $\begin{array}{l}\text { Insulation } \\
\text { Thickness }\end{array}$ & 50 & $\mathrm{~mm}$ \\
\hline Annular Gap & 21 & $\mathrm{~mm}$ \\
\hline Outside Diameter & 304.8 & $\mathrm{~mm}$ \\
\hline \multicolumn{3}{|c|}{ Pipe Dimension of Liquid Phase } \\
\hline Inside Diameter & 25.4 & $\mathrm{~mm}$ \\
\hline $\begin{array}{l}\text { Insulation } \\
\text { Thickness }\end{array}$ & 20 & $\mathrm{~mm}$ \\
\hline Annular Gap & 17 & $\mathrm{~mm}$ \\
\hline Outside Diameter & 101.6 & $\mathrm{~mm}$ \\
\hline \multicolumn{3}{|c|}{ Pipe Dimension of Water Spray System } \\
\hline Inside Diameter & 133.1 & $\mathrm{~mm}$ \\
\hline Wall Thickness & 5.4 & $\mathrm{~mm}$ \\
\hline Outside Diameter & 138.5 & $\mathrm{~mm}$ \\
\hline $\begin{array}{l}\text { Nominal } \\
\text { Diameter }\end{array}$ & DN 125 & \\
\hline
\end{tabular}

4. The location of each components should be considered based on the regulation to achieve the optimum design arrangement. According to GL rules, LNG tank can be located in the opened space and closed space. In this design arrangement, the LNG tank located in the open space because the laboratory doesn't have enough space. The gas valve unit is enclosed design type because it can be located inside the engine room and it's not require installation in an explosion-proof gas valve unit room. All the equipment of gas valve unit type enclosed design is mounted inside a gas tight casing and it can minimise the installation costs. LNG pump and vaporizer are located in the open space to avoid a gas explosion when operating failure occurred on LNG pump and vaporizer. 


\section{REFERENCES}

[1] Kazuaki Yuasa, Katsuya Uwatoko, Junshiro Ishimaru, "Key Technologies of Mitsubishi LNG Carriers," Mitsubishi Heavy Industries, Ltd., Japan, 2001.

[2] D. G. M. Wuersig, "LNG as Ship Fuel," DNV GL, Hamburg, Germany, 2015.

[3] Mads Lyder Andersen, Niels B. Clausen, Pierre C. Sames, "Costs and benefits of LNG as ship fuel for container vessels," Research and Rule Development, Hamburg, Germany, 2013.

[4] Marine Installation Manual, Switzerland: Wartsila RT-Flex 50 DF, 2015.

[5] H. E. Hernes, "Active and Passive Measures to Maintain Pressure in LNG Fuel System for Ships," Department of Energy and Process Engineering, NTNU, Trondheim, Norway, 2015.

[6] Saval, B.V., "Fixed Water Spray Cooling System," Saval B.V, 2013.

[7] MAN 51/60DF Project Guide, Augsburg, Germany: MAN Diesel \& Turbo, 2017.

[8] Semin, Iswantoro A., Faris F. "Performance and NOx Investigation on Diesel Engine using Cold EGR Spiral Tube: A Review." International Journal of Marine Engineering Innovation and Research., vol. 1, no. 3, Jun. 2017

[9] Zuhdi A., Busse W., Clausthaldi. "Fluid Flow Analysis of Jacket Cooling System for Marine Diesel Engine $93 \mathrm{KW}$ ”. International Journal of Marine Engineering Innovation and Research., vol. 1, no. 2, Mar. 2017.
[10] Semin, NS Octaviani, AP Gusti, MB Zaman. (2016). Power Performance Characteristics Investigation of Gas Engine using New Injector. International Journal of Applied Engineering Research 11 (11), 7462-7466.

[11] Semin, AP Gusti, NS Octaviani, MB Zaman. (2016). Effect of New Injector on the Torque Performance Characteristics of Gas Engine. International Journal of Applied Engineering Research 11 (11), 7467-7471.

[12] AP Gusti, Semin. (2016). The Effect of Vessel Speed on Fuel Consumption and Exhaust Gas Emissions. American Journal of Engineering and Applied Sciences 9 (4), 1046-1053.

[13] Hari Prastowo, Semin, et al. (2016). Investigation of Fuel Flow Velocity on CNG Engine using New Injector, Asian Journal of Engineering and Technology 4 (2), 38 - 43.

[14] Semin. (2015). Analysis of Biogas as an Alternative Fuel for Electric Generator Engine in Bawean Island - Indonesia. International Journal of Applied Engineering Research 10 (16). pp. 35313-35317.

[15] Semin. (2015). Investigation the Effect of Injector Nozzle Multi Holes Geometry on Fuel Spray Distribution Flow of CNG Engine Based on Computational Modeling. International Journal of Applied Engineering Research 10 (15). pp.36087-36095.

[16] Semin, B Cahyono, Amiadji, RA Bakar, (2015). Air-fuel Mixing and Fuel Flow Velocity Modeling of Multi Holes Injector Nozzle on CNG Marine Engine. Procedia Earth and Planetary Science $14,101-109$.

[17] Semin and R.A. Bakar. (2014). Computational Modelling the Effect of New Injector Nozzle Multi Diameter Holes on Fuel-Air Mixing Homogeneous of CNG Engine. International Journal of Applied Engineering Research. Volume 9 (21). pp. 9983.

[18] Semin and R.A. Bakar. (2013). Simulation and Experimental Method for the Investigation of Compressed Natural Gas Engine Performance. International Review of Mechanical Engineering 7 (7).

[19] Semin (2012) .Injector Nozzle Spray on Compressed Natural Gas Engines: a Technical Review. International Review of Mechanical Engineering, Vol.6 No.5. 